\title{
How to End an Orally-Derived Epic Poem ${ }^{\star}$
}

\author{
ADRIAN KELLY \\ St. Anne's and Balliol Colleges, Oxford
}

SUMMARY: This article argues that the extant works of early Greek hexameter poetry reveal a consistent strategy of closure, one that is based around the manipulation of doublet structure. The discussion begins by examining this wellknown compositional technique, specifically the 'increasing' doublet (ID) where a smaller element is placed directly before a larger one, and it aims to demonstrate the widespread distribution and variety of these doublets, as well as their common function: to encourage the audience to summon their memory of the first element, and so augment the importance of the current, larger one. Attention is then turned to the endings themselves, in order, of the Iliad, Odyssey, Works and Days, Theogony and Shield of Herakles. Employing the same type of retrospective aesthetic, the poets use a 'decreasing' doublet $(D D)$ to emphasize the greater significance of the prior, larger element. By directing the audience to this disparity in scale, the poets discourage them from expecting continuation, and so signal the close of their texts.

THE ENDS OF ANCIENT NARRATIVES CAN OFTEN SEEM PUZZLING AND OBSCURE, ${ }^{1}$ and the epic texts of the Archaic period are no exception. Perhaps reassuringly, it is not simply a matter of modern misunderstanding, for the ancients themselves were uncertain about the parameters of the Homeric and Hesiodic poems, and the manuscript traditions readily show just how evanescent their

${ }^{\star}$ I would like to thank Bill Allan, Ruth Finnegan, John Miles Foley, Sophie Gibson, Bryan Hainsworth, John Havard, Paul Allen Miller, Matthew Leigh, Oliver Taplin, Oliver Thomas and Stephanie West, as well as several of my students at Oxford, for their help on this article and its material. They are not responsible for the argument and its shortcomings. I use arabic numerals for specific citations from the Iliad and Odyssey, and Greek letters (capitals for the Iliad) for citations from books alone. All translations are mine.

${ }^{1}$ For a range of practical and theoretical discussions of closure, cf. Roberts, Dunn \& Fowler 1997. 
closure was felt to be. The Iliad, for example, was reputed to have an alternative ending leading straight into the Aithiopis (or Memnonis), ${ }^{2}$ the beginning of the Hesiodic Catalogue of Women is contained in several MSS at the end of the Theogony (Theogony 1021-2 = Frg. 1.1-2 M-W; Dräger 1997: 1-26; cf. Clay 2003: 162-64; also below, pp. 389-96), the Works and Days is similarly joined to the Ornithomanteia (cf. Schol. vet. ad 828a; also F 312 \& 355 M-W; West 1978 ad 828: 364-5; also below, pp. 387-89), the Hesiodic Shield of Herakles clearly has some sort of relationship with the Catalogue of Women (Shield 1-56 = F 195.8-64; Russo 1965 ad Shield 1-3: 69; ad 55: 85-6; also below, pp. 396-98 and n48), ${ }^{3}$ and the ending of the Odyssey is a notorious zetema (cf. Heubeck 1992: 353-55, 356-58, 381-82, 405-6; also below, pp. 384-87 and $\mathrm{n} 26)$. In fact, as a body of poetry, early hexameter epic seems in this respect to have presented particular difficulties for some of its ancient audiences.

This state of affairs need not be treated-initially, at least-as yet more evidence of the rather cavalier attitude towards textual integrity sometimes found in the ancient world. Just as the Homeric Vitae, beyond the familiar question of their historical reality, reveal contemporary perceptions of epic poetry, ${ }^{4}$ so this blurring of early textual boundaries reflects a contemporary sense of the continuative quality to this poetry. That is, a traditional singer could switch from one oí $\mu \eta$ ('song-path') to another, ${ }^{5}$ and indeed would have to be able to do so in order to respond to the audience's desires, as Phemios and Demodokos are asked to do in the Odyssey (1.337-44, 8.492-98). An oral poet commanding $\pi \alpha \nu \tau o i \alpha_{\imath}$ oîn $\alpha_{\mathrm{l}}$ could run all the way through his repertoire, linking stories and characters almost at will, so the 'continuations' reflect one of early Greek epic's most important characteristics-the interdependence and transferability of its stories and themes. Perhaps, then, the question should be framed in the following way: how would a poet trained

${ }^{2}$ Cf. Schol. T ad 24.804, with Erbse 1977 ad loc.: 642; Bernabé 1987 ad Aithiopis F 1: 69-70; Burgess 2001: 140-42. None of the following 'joins' may be securely dated, though the Alexandrian period (from which the Homeric and Hesiodic scholia mainly stem) may be considered the terminus ante quem.

${ }^{3}$ For Hesiodic fragments and scholia, see di Gregorio 1975, Pertusi 1955, and Merkelbach-West 1967.

${ }^{4}$ Cf. Graziosi 2002. For other recent approaches, cf. West 1999; Foley 1999: 49-61.

${ }^{5}$ On the oilu in early epic, cf., e.g., Becker 1937: 36-7, 68-9; Thornton 1984: 148-49; Ford 1992: 40-48; Nünlist 1998: 228-83. I take this word to connote the transferability of story-patterns and traditional themes in early Greek epic, which should serve to position this discussion within the oralist school of Homeric scholarship, though only the immediately relevant works will be cited in what follows. 
in this style of composition bring the performance or text to a satisfactory end? How would he overcome the audience's expectation of continuation or, perhaps better, the possibility of that continuation?

Admittedly, several factors might induce the close of a performance, such as an audience losing concentration or cohesion, or simply not approving of the song, and the poet himself might postpone the tale for a subsequent performance. By the same token, it is very difficult to imagine that highly regarded singers would not have been allowed, at least on occasion, to complete their songs without such interruptions, for which eventuality they would have evolved the appropriate techniques. ${ }^{6}$ In this circumstance, where the óor $\delta$ ó $\varsigma$ is free to close his poem where he will, how does he signal to his audience that the narrative is coming to a close? This is one of the most crucial questions in early Greek poetry, for on it hangs the ability of the tradition, its poets and their audiences to conceive of a unified text; so too, therefore, should hang the modern conception of the integrity of the texts derived from that tradition.?

In this article, I will argue that the endings of early epic poems do reveal a consistent principle of closure. ${ }^{8}$ This strategy is predicated on repetition, that most "oral" of Homeric and Hesiodic characteristics, and more precisely on the very well-known technique of doublet construction. In short, the poets

${ }^{6}$ For performance interruption and postponement, cf. Lord 1960: 17; Finnegan 1977: $54-58$.

${ }^{7}$ It is, of course, important to recognize that written texts are not the same thing as performances of stories, and there is no way of knowing that the extant works of early Greek hexameter reflect an actual as opposed to an idealized performance locus, such as that envisaged in Lord's dictation theory; cf. Lord 1953; Janko 1998. This is why it is best to consider the genre and its features "orally-derived" rather than "oral"; cf., e.g., Foley 1999: ch. 1; Foley 2002: esp. 146-87. The distinction allows us to consider the influence of the oral tradition without excluding the operation of "literate" factors. Of course, the fact of derivation should not be underplayed; any discussion of the compositional techniques of early Greek epic poetry must consider the specifically performative factors which could lie behind them.

${ }^{8}$ As J. M. Foley points out to me, this argument assumes a certain permeability to early Greek epic, given that this strategy is "cross-generic." Such an ability is in fact characteristic of archaic hexameter poetry, with the Dichtersprache itself providing the most obvious example of the ways in which very different compositions can share the most basic building blocks and strategies. The epic tradition is a multi-faceted creature, and the particular form of any of its products depends as much on poetic preference as it does on the audience's desires at the moment of performance. In short, what works for one poet may work for another, and even for a different "type" of song, as long there are no conventions to prevent such a transfer, such as those governing the closure of the Hymns (below, n9). 
generate what I shall call the "decreasing doublet" (hereafter $D D$ ) in order to discourage their audiences from expecting continuation, and so to herald the end. An appreciation of this strategy can allow a structurally driven judgment about the worth of the paradosis's reflection of textual integrity, and the authenticity of the continuations, at least in terms of the extent to which the MSS reflect the closural practices of poets trained in this tradition.

It may be remarked that such a demonstration can only prove that these texts were originally conceived with a measure of Selbständigkeit, one can never know who composed or conjoined the other texts listed above, whether later poets tried to pass off their own work by linking it to the 'classics,' whether ancient scholars simply thought they should be linked - and so on ad infinitum. What can be suggested, however, is that the extant texts of Archaic epic bear the traces of a closural strategy that would seem to reveal at least some poetic sense of their unity and integrity. ${ }^{9}$

\section{INCREASING DOUBLETS (ID) IN EARLY HEXAMETER POETRY}

Doublet structure is, of course, very far from a new discovery. At least since Fenik's excellent monograph on the Odyssey (Fenik 1974: 133-207), ${ }^{10}$ it has

${ }^{9}$ I shall deal primarily with the Iliad, Odyssey, Theogony, Works and Days and Shield of Herakles, mainly because they are the only poems preserved more or less complete. I exclude the Homeric Hymns because they do not employ the DD strategy. This is not fatal for my argument, for compositions of this sort were originally intended as preludes to other epic performances, a fact signaled by the conventional $\chi \alpha \hat{i} \rho \varepsilon$ transition with which

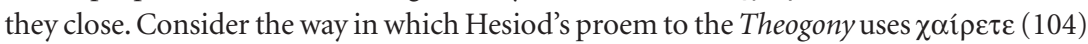
to separate the opening hymn to the Muses (1-103) from the programmatic statement (106-15); cf. Minton 1970; Thalmann 1984: 134-44; Stoddard 2004: ch. 3. Whatever the relationship of the extant hymns to their original performance locus, they continue this practice; cf. Homeric Hymns 1.20-1, 2.490-95, 3.545-46 (also 165-68), 4.579-80, 5.292-93, 6.19-21, 7.58-59, 9.7-9, 10.4-6, 11.5 etc.; also van Groningen 1958: 73-74; Janko 1981; Fröhder 1994: 57-60; Furley \& Bremmer 2001: 61-62.

If the following argument be accepted, then the $D D$ criterion could also be used to aid in the ongoing process of reconstructing the Catalogue of Women (cf. Hunter 2005 for recent efforts), and to provide a much better estimation of the extent to which the original poems of the 'cycle' are removed from their summaries in Apollodoros and Proklos. That task, however, is beyond the scope of this article. (I take this opportunity to note that I do not follow Gregory Nagy's challenging "evolutionary" theory of Homeric textuality; cf. esp. Nagy 1996. As Janko 1999 points out, the linguistic fixity of early Archaic epic argues for an early textual fixity which is - as yet -insufficiently accounted for by Nagy's model.)

${ }^{10}$ Fenik found able predecessors in van Otterlo 1944: 31-33; van Groningen 1958: 83-93. Though all these authors deal with a range of repetitions, none treats precisely the sequences with which I am concerned. Fenik, for example, treats doublets of person, 
been respectable to admire Homer's doublets as products of his artistry and skill rather than the clumsy interventions of a later poet or a redactor of some sort. Of all the doublet types in hexameter poetry, I shall focus in this section on the ways in which the Archaic epic poets use a smaller element or episode before a larger, contiguous example; I shall argue that the audience's understanding of the second element is considerably enhanced by their reminiscence of the first, and their awareness of a disparity in the scale of its construction.

To begin with Homer, a simple doublet occurs in Iliad $\Theta$, where the first Greek counterattack led by Diomedes is paralleled by the second counterattack centered around Teukros's aristeia. A comparison is clearly intended: in each case there is a conversation between the leading Greek hero and another character about their motivation (138-71 | 280-99); this hero drives the fighting and kills Hektor's charioteer with an alienum vulnus (119-24 | 309-16) before suffering a setback; Hektor ends up in front of the Greek camp (172-97 I 335-49); and there is a divine episode detailing Here's reaction to the situation, and her determination to intervene (198-212 | 350-96). ${ }^{11}$

Generally larger and more complex, the second sequence leads into the abortive attempt by Here and Athene to intervene in the narrative, something furiously denied by Poseidon at the end of the first sequence when Here had suggested it to him. Comparison between the two brings to bear on the coming action a remembrance of this earlier refusal to intervene on the grounds of Zeus's greater power, thus underlining both the fact and the reason for the failure of the goddesses' mission. Their aborted intervention is not only proleptic of later divine insurrections against the Dios boule in the poem, but also leads straight into Zeus's first explicit statement of that plan in the fractious divine agore which closes the day (442-82). The doublet is important for the

action and motif, as well as relatively limited narrative series. Yet the observations drawn from his (and the other) studies are readily applicable to larger sequences, such as the relationship between Telemakhos's nostos and his father's, although in this case the poet has interrupted the introduction and course of the earlier smaller sequence ( $\alpha-\delta$ । o ff.) and inserted the larger ( $\varepsilon-\xi$ ff.), so as to harmonize the returns of the two Laertidai to Ithaka and increase the parallels between them. An equal element in this, of course, is the contrast: Telemakhos is not (yet) of his father's abilities, and his voyage neither as dangerous nor, ultimately, as interesting; cf. below, pp. 377-80, for a similar interrupted doubling in Hesiod's Theogony. There are doubtless many nostoi in the Odyssey, and Menelaos's return is in many ways an obvious and important doublet to Odysseus's; cf. Powell 1970; de Jong 2001: 591-93. There may, however, be more than one pattern operating at a time, and the point remains that the two most extensively narrated nosto $i$ in the poem are those of father and son; cf. also de Jong 2001: 589-90.

${ }^{11} \mathrm{Cf}$. Willcock 1995 for a general discussion of structure in $\Theta$. 
poet as he composes, giving a direction for his narrative to follow, but also for his audience, for they focus on the larger second sequence as the fulfillment of the themes explored in the first sequence. It is a concentrating device of great semantic utility, which functions by encouraging an understanding of the narrative present by its (doublet) past.

This strategy is not confined to relatively small stretches of narrative. The second $(\Theta)$ and third $(\Lambda-\Sigma)$ battle days in the Iliad comprise a similarly "increasing" doublet (hereafter ID). Begun by the isolation of Zeus and his presence on the battlefield despite the other gods' wishes (8.41-52 | 11.78-83, 181-4), each day is built on temporary Greek success followed by inexorable Trojan gains, which Here tries to spoil by acting with another deity (8.350-96 | 14.153-361) before an open threat from Zeus (8.461-84 | 15.13-78); the day's fighting ends with the Trojans camped on the plain and holding an agore about their intentions (8.489-542 | 18.243-313), in which Hektor dominates the deliberations (8.493-541 | 18.284-313). ${ }^{12}$ The increase in size between the two sequences and their constituents is obvious, and the audience is able once more to compare the situations as they occur in a dynamic narrative. By the end of the third day of battle, the earlier lessons - of Zeus's disfavor towards the Greeks, the Trojans' success, and the reluctant obedience of the other gods-have all been replayed on a much larger scale, and now with greater or more permanent ramifications for all the players: while Teukros was the only major figure even wounded in $\Theta$, Sarpedon and Patroklos are now dead and Hektor's fate sealed. Indeed, at the close of $\Theta$ everything looked rosy for Hektor, but the situation at the end of the agore in $\Sigma$ is markedly less happy. Comparison with that earlier sequence can only increase the audience's understanding of Hektor's delusion in persisting with the same course of action-now that Akhilleus has shown his desire to rejoin the fighting. In short, as Schadewaldt observes,

[d]ie absichtlich so skizzenhaft gehaltene кó 'Dublette' kleineren Maßstabs zu der großen Niederlage der Gesänge $\Lambda$-O. Eben als 'Dublette' ist der Gesang nämlich das, was er sein soll: Vorklang, Vorbereitung, in vielen hier angeschlagenen Einzelthemen wie in seiner Gesamtentwicklung. ${ }^{13}$

${ }^{12}$ One could multiply the parallels to include a temporary defeat for Hektor at the hands of a major Greek hero (8.116-29| 11.310-60, 14.402-32), unsuccessful (i.e., nonlethal for the target hero) arrow strikes for Paris (8.81-82। 11.369-78, 505-7, 581-84), the pairing of Teukros and Aias which nonetheless fails to cause lasting difficulty for Hektor (8.266-334f. I 12.370-407f., 15.442-84f.), and the mission of Iris to prevent actual conflict between a recalcitrant deity and Zeus (8.397-425 | 15.157-219). Note the increase in size, and sometimes number, of the episodes in the second sequence; $\mathrm{cf}$. further Schadewaldt 1966: 102-27.

${ }^{13}$ Schadewaldt 1966: 127: "the kolos makhe is deliberately constructed roughly; it is, if one wishes, a 'doublet' of smaller scale to the large defeat of Books 11-15. Precisely as a 
Hesiod also employs a large scale $I D$, if not quite so large as the one above, in the parallel between the first revolution in the Succession Myth (Theogony 154-210) and its much more elaborate second stage (617-819). ${ }^{14}$ In the first sequence Kronos overthrows Ouranos at the instigation of Gaia; in the second Zeus defeats Kronos (again with the aid of Gaia, and Rheia), though more attention is given to the Titanomachy. ${ }^{15}$ The genealogies are also constructed around this doublet structure, for the first overthrow occurs after the catalogue of Gaia's (and Ouranos's) children (126-53), who are the important players in their father's defeat. The second is more momentous, involving many more characters and resulting in the present order of the world-the supremacy of Zeus - and so it comes only after the complete genealogy promised in the 'programmatic' section (that is, 104-115; cf. above, n9) of the proem

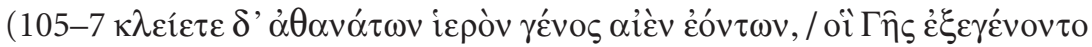

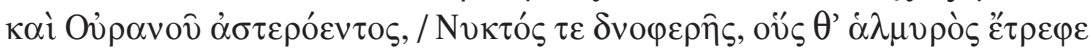

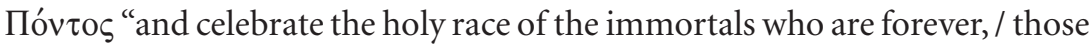
who were born from Ge and starry Ouranos / and dark Nyx, and those whom briny Pontos raised"), where the cast includes the children and grandchildren of the three named groups. See Figure 1 for clarification:

'doublet' the song is actually what it should be: foreshadowing, preparation, in many single themes (here shortened) as in its entire development." I would extend this to the end of the third battle day, given the parallels with the end of the second day enumerated above.

${ }^{14}$ For treatments of the poem's structure, cf. van Groningen 1958: 256-82; Kirk 1962; West 1966: 31-39; Schwabl 1966; Thalmann 1984: 38-45; Hamilton 1989: 4-43.

${ }^{15} \mathrm{Cf}$. below, n16, for the structural and semantic implications of the poet's choice in this respect. 


\begin{tabular}{|c|c|c|c|}
\hline I & $\begin{array}{l}\text { A } \\
\text { B }\end{array}$ & $\begin{array}{l}126-53 \\
154-210\end{array}$ & $\begin{array}{l}\text { Children of Gaia (and Ouranos) } \\
\text { Deposition of Ouranos }\end{array}$ \\
\hline II & A & $\begin{array}{l}\text { (1) } 211-32 \\
\text { (2) } 233-336 \\
\text { (3) } 337-616 \\
617-819\end{array}$ & $\begin{array}{l}\text { Children and grandchildren of Nyx } \\
\text { Children and grandchildren of Pontos } \\
\text { Grandchildren of Gaia (and Ouranos) } \\
\text { (Deposition of Kronos) }^{16} / \\
\text { Titanomachy }\end{array}$ \\
\hline
\end{tabular}

Figure 1. Theogony 126-819

${ }^{16}$ This is separated from the Titanomachy by the generation of the Iapetidai and the story of Zeus' contest with Prometheus (507-616), and is very briefly narrated at the end of Rheia's progeny, i.e. it is actually located within IIA3 above. The result is itself an $I D$, within the larger doublet of which IIA3 is composed.

\begin{tabular}{llll}
\hline [IIA3] & i $337-452$ & $\begin{array}{l}\text { Gaia's grandchildren I } \\
\text { (no conflict with Zeus) }\end{array}$ \\
\hline & ii & $453-616$ & $\begin{array}{l}\text { Gaia's grandchildren II } \\
\text { (conflict with Zeus) }\end{array}$ \\
& & & Kronidai \\
& a & $453-58$ & Overthrow of Kronos \\
& & $459-506$ & Iapetidai \\
& & & $\begin{array}{l}\text { Overthrow of } \\
\text { Prometheus }\end{array}$ \\
\hline
\end{tabular}

The poet pairs the victories of Zeus over Kronos (iib) and Prometheus (iib') to emphasize the latter, which prepares the audience for the way in which IIB is not just Zeus's turn at paternal conquest, but his defeat of the entire generation of older gods. This structure eases the transition between IIA 3 and IIB by providing increasingly large and important examples of Zeus's victories before the Titanomachy itself, and the resulting triple victory (not his last; cf. pp. 389-91 and Fig. 5) underlines his power, as well as the permanence and thoroughness of the subsequent settlement at the end of IIB; cf. also West (1966) 16-18 for another arrangement (I am particularly indebted to Oliver Thomas for intricate discussion of this issue). 
This basic doublet gives an overall structure to an otherwise confusing array of genealogies, in which the poet has interrupted the typical sequence of children - grandchildren in Gaia's genealogy in order to insert the complete genealogies of Nyx and Pontos between the generations of the Ouranidai. The poet thereby prepares the audience for the greater significance of the Titanomachy in IIB simply by putting a larger cast characters on the stage, and he also provides (in the form of Kronos and Prometheus; cf. n16) smaller preparatory examples for the victory of Zeus in the battle with the Titans. Together, these factors underline both the thematic primacy of Zeus's order in the world, and the reasons why he is both like and unlike Kronos in the process of generational change, for he is both a paralleled, but decidedly more successful, figure.

Moreover, at the end of the Titanomachy Zeus is chosen (or, rather, confirmed) as the new leader and divides the gera of the immortals (881-85) in such a way as to avoid the type of anger which drove the Hundred-Handers to assist Zeus's rebellion against Kronos (501-6; 616-23), fulfilling the promise

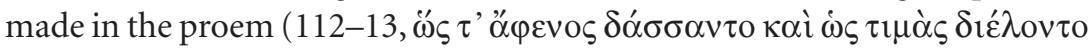

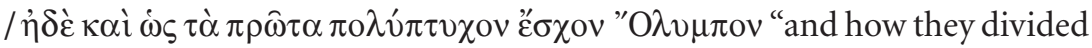
the wealth and how they chose their timai / and even how they first obtained many-folded Olympos"). This "apportioning" aspect to his power has already been established in IIA1-3, as he grants extraordinary $\tau \iota \mu$ í to Styx and her children (386-403) and then Hekate (411-52) before the reciprocal advantages of freeing the Hundred-Handers (501-6) and the appropriation of Prometheus's (superficially) successful attempts at determining the portions of gods and men. ${ }^{17}$ Furthermore, these examples show that Zeus's control is

\footnotetext{
${ }^{17}$ Hesiod goes to some lengths to point out Zeus's (eventual) control over Prometheus's several acts of rebellion, by linking the first sacrifice to Zeus's intention to honor Herakles (526-34) and to plan evil for men (551-52), resulting in the witholding of fire (562-69) and the inflicting of woman on mankind (570-612). Hence the conclusion of IIA3 stresses the difficulties of evading Zeus's plans (613-16), for they ensnared even Prometheus к $\alpha i$

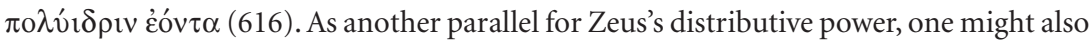
compare the honour granted to Pegasos (285-86).

At every stage the poet leads the audience forward beyond the individual character, and his or her moment of generation, into the establishment (and nature) of Zeus's reign. As with the Homeric poems, the catalogue form in Hesiod prepares the audience for the actions on which the personnel named are to be engaged; just as the enormous catalogues of B in Greek are proleptic of the entire Iliad's fighting and not just its first day, so the most important generational overthrow among the gods is only narrated when Hesiod has the fullest possible cast of characters. Not all of them need to take a named part, any more than every Greek or Trojan need be mentioned in the Iliad's coming battle narrative, but they are an indication of the importance of that action.
} 
intimately linked with the support he receives from female deities, who are usually the agents of generational overthrow in the Succession Myth (cf. Bonnafé 1985: ch. 5; Clay 2003: 129-40). In this he is partially like his father, who had also received Gaia's aid, but mostly unlike him, for Zeus will not make the same marital mistakes, instead emasculating (as it were) Here's destabilizing potential by having children from a variety of sources.

Thus, once more, an ID not only gives shape to the poem, but also greatly enhances the audience's understanding of its themes and meaning. One final Hesiodic example, from the Works and Days, ${ }^{18}$ may suffice to make clear this strategy's typicality in, and importance for, early hexameter poetry. After the Ages of Man myth (106-73) and the dire predictions for the present and future with which it closes (174-201), Hesiod links the "mythical" section and the Works and Days section with two progressions constructed around the opposition between the basileis and Perses as his addressees (see Fig. 2).

One can see the by now standard increase in scale from the first to the second sequence, both as a whole and in terms of its constituent elements. There is also a progression from indirect to direct advice in the course of the doublet. In IA, Hesiod makes no direct address to the basileis after mentioning them (202), being similarly oblique in the anthropomorphic narrative of IB, in which (after the initial vocative) there are only third person descriptions of Hybris, Dike and so on, and no direct instruction of Perses himself. This indirectness is then modified in II, for Hesiod interrupts his generalized musing in IIA with an imperative addressed to the basileis (263 $\tau \alpha \hat{\tau} \tau \alpha \varphi v \lambda \alpha \sigma \sigma o ́ \mu \varepsilon v o r$, $\beta \alpha \sigma \imath \lambda \hat{\eta} \varsigma$, $\imath \theta \dot{v} v \varepsilon \varepsilon \varepsilon u^{\prime} \theta 0 v \varsigma$ "guarding these things for yourselves, basileis, keep your speech straight"), and it is entirely broken down in IIB, as the poet moves into increasingly concrete instructions about daily life and practice, with explicit mentions of its addressee (e.g. 298-99, 306, 312 etc.). ${ }^{19}$

Thus, firstly, the ID serves as the framework for a progression from less to more personalized instructions. Secondly, and in keeping with other doublets already discussed, the audience is encouraged - indeed compelled - to recall the first sequence, for it is only at the start of IIB (277-80) that the point of

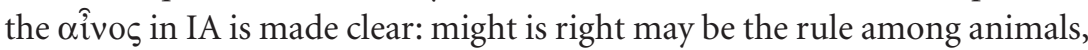

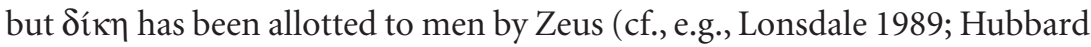

${ }^{18}$ For treatments of this poem's structure, cf. Kerschensteiner 1944; van Groningen 1958: 283-303; Verdenius 1962; Walcot 1961; Diller 1962; Kumaniecki 1963; Nicolai 1964; Blusch 1970: ch. 5; West 1978: 41-59; Peabody 1975: 236-72; Thalmann 1984: ch. 2; Heath 1985; Schmidt 1986: 12-19; Hamilton 1989: 47-87; Riedinger 1992; Lardinois 1999.

${ }^{19} \mathrm{IIB}$ also comprises the first sequence in the concluding doublet; cf. below, 387-88 (= IA in Fig. 3). 


\begin{tabular}{|cccc|}
\hline I & A & $202-12$ & $\begin{array}{l}\text { (Basileis) Fable of Hawk and Nightingale } \\
\text { (Perses) Hybris, Dike, Horkos, Eirene }\end{array}$ \\
& B & $213-47$ & (Basileis) 'guards of Zeus', Dike, eye of \\
II & A & $248-73$ & Zeus \\
& B & $274-382$ & (Perses) Dike, Limos, and instructions
\end{tabular}

Figure 2. Works and Days 202-382

1995). Dike, obviously, is a key figure in the anthropomorphic narratives of IA, IB and IIA, so the point of the ID is to establish in every way the primacy of this figure before its ramifications are enumerated in the Works and Days sections.

Needless to say, other narrative patterns work alongside the doublet sequences identified above, and I make no claim here to an exhaustive appreciation of the full structural richness of early hexameter poetry. Several different patterns of articulation may be combined, for (to take only some examples) chiasmus, repetition, and ring composition-all on scales large and small-have an important role to play in the construction of these poems. ${ }^{20}$ No single description should pretend to be exclusive, but it would be absurd to reject the existence or import of these doublet patterns solely on the basis that other principles may also be discerned within the narrative.

Furthermore, all the examples have been predicated on the (allegedly problematic) idea of significant parallelism as opposed to the unconscious repetitions of an oral poet composing (at least in the case of the Iliad and Odyssey) a monumental text. Sometimes it is indeed difficult to see whether a doublet is intended to be significant (cf. Fenik 1974: 159-60), but the interpretative

${ }^{20}$ This qualification applies also to the discussion of the next section. There is not the space here adequately to address the other structural patterns-or the relevant bibliography—one may find; cf. nn14 (Theogony), 18 (Works and Days), 22 (Iliad), 26 (Odyssey) and 48 (Shield) for some individual treatments. 
abilities of a traditionally attuned audience are not to be downplayed nor limited to an appreciation only of generic narrative features. ${ }^{21}$ Some patternings, particularly when they are contiguous, are so obvious, and obviously useful, that it would be almost recalcitrant to deny that the composer intended his audience to notice and use them.

Building on the work of many other scholars (most notably van Groningen, van Otterlo, Fenik and Schadewaldt), this (very) brief survey has tried to show the presence in early hexameter poetry of the ID as a structural strategy on several scales of composition. The examples have suggested a considerable semantic utility to the manipulation of the audience's attention in this way, wherein the larger example is magnified and contextualized by reference to its smaller partner. This process of comparison encourages an interpretative primacy, if you will, for the second element, by enabling a completion of the themes or actions exhibited in the first sequence, and so binding the narrative together. In this process, the larger element becomes the prime object of focus, illustrating again the truth of Austin's (1966) dictum about the proportional relationship between size and importance in early Greek epic.

\section{DECREASING DOUBLETS ( $D D$ ) IN EARLY HEXAMETER POETRY}

In this section I argue that the endings of the Homeric and Hesiodic poems employ another type of doublet, this time of decreasing dimensions. Again, a disparity in scale directs the audience towards the larger element as the more significant, though this time the larger element is the prior one. None of this denies the significance or importance of the smaller element, but it is a question here of poetic direction, and the audience's appreciation of scale in the interpretation of epic narrative. By holding their attention on that prior element, the poets discourage, or refuse to encourage, their awareness that the song could continue.

\section{a. The Iliad and Odyssey}

The end of the Iliad is universally, and rightly, praised for its pathos and beauty. ${ }^{22}$ But these qualities, particularly when invoked to condemn the end

${ }^{21}$ For an excellent examination of the interplay between generic and specific references in the Odyssey's use of the hospitality motif, cf. Reece 1993.

${ }^{22}$ Cf., e.g., Reinhardt 1961: 462-506; Taplin 1992: 279-84; Seaford 1994: ch. 5. Structural studies of the Iliad are abundant, and only some are listed here; Myres 1932; Whitman 1958: 249-84; Nicolai 1973: 141-58; Thalmann 1984: 45-50; Thornton 1984; Taplin 1992: esp. ch. 1; Heiden 1996 inter al.; Schein 1997; Latacz 2000: 145-57. 
of the Odyssey on grounds of its inferior emotional impact ( $v e l$ sim.), are a somewhat unstable ground on which to begin a structural analysis. ${ }^{23}$ Instead, it is more useful to acknowledge that Hektor's is the second major heroic burial at the end of the Iliad; Patroklos's funeral began in $\Sigma$ with the recovery of his corpse (232-33), and it is not complete (formally at least) until the end of $\Psi$. Hektor's funeral, by contrast, extends for a little over a hundred verses (24.696-804). The diminution in scale and structural complexity is obvious, yet the funeral sequence is recognizably the same. Just as they were linked

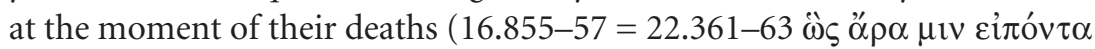

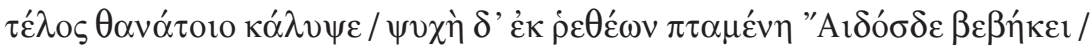

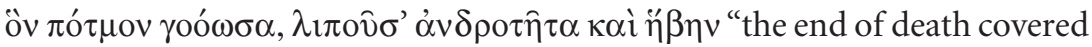
him when he had spoken thus / and his soul taking flight from his limbs was gone to Hades / lamenting its fate, leaving manliness and youth"), so too Patroklos and Hektor are paired structurally in the process of their funerals. This time, however, the second burial looks back to the first as the most elaborate-and so most important-example of the theme.

This is not to preclude the significance of Hektor's funeral, simply to recognize that a doublet has been set up in which (as with the ID) the audience are summoning the earlier scene as they experience the final one. By contrast with the earlier example, the second sequence is far less elaborated than the first, though it contains all the elements-mourning, burial rites, construction of a tomb, celebration of the dead hero through a communal activity and so on. ${ }^{24}$ In other words, the audience is being directed back into the text not in order to magnify the current scene but to set it in a larger context. There are, of course, significant contrasts between the ways in which the funerals are conducted, and any analysis of the poem is immeasurably poorer without an appreciation of this dynamic; for instance, communal activity in Troy is a feast in Priam's house, in the Greek camp it is the Funeral Games, with all their renewed antagonism and barely concealed rivalry over $\tau \imath \mu$ ' (cf., e.g., Postlethwaite 1995). Or, again, the women weeping over Patroklos are

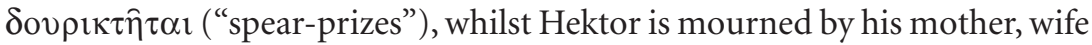
and sister-in-law. The claims of his immediate family are thus emphasized in the second sequence, and the diminution in scale serves also to achieve

\footnotetext{
${ }^{23}$ Nonetheless, one should not ignore the way in which both poems satisfy a sense of thematic closure; as Bryan Hainsworth points out to me, "which is the better signal to an audience, (thematic) completion or diminuendo? Or completion terminated by diminuendo?" I would argue for the last but, though this article is concerned mainly with the structural aspects of the question, I hope also to demonstrate the thematic utility of the strategies examined here.

${ }^{24} \mathrm{Cf}$. Edwards 1986 for the narrative conventions of the Homeric funeral.
} 
a narrowing in the social focus of the funeral, and a consequent emotional intensification. ${ }^{25}$

The obvious next step is to look for this type of doublet closure to the Odyssey. In stark contrast to the Iliad, literary judgments of its ending are frequently negative. ${ }^{26}$ Yet it has the same type of decreased sequence, with the battle against the suitors' families (24.493-548) reaching back to the much larger battle with the suitors themselves in $\chi$. That some type of confrontation with the families is expected is indicated extra-textually by Proklos's report of the Telegonia (arg. 3 Bernabé 1987) which begins with the suitors' funerals, but inside the poem by several hints at the wider social implications of Odysseus's absence and his revenge (cf., e.g., Od. 2.21-2, 26-7, 39-79, 160-76; $3.212-15 ; 20.41-43 ; 23.117-22 ; 24.451-62$ ). Moreover, the resolution of the potentially never-ending process of feud and counter-feud is underlined by a contrast between the freedom with which Odysseus and his men merrily kill the suitors, and the limitations (almost ignored on the ground) placed by both Athene and Zeus on their attack on the relatives (24.529-33, 539-44). As with the Iliad, the scale and elaboration of the two battles is markedly different; the earlier conflict employs a much fuller range of combat descriptions and motifs over several hundred verses (21.393-22.389 ff.), whilst the latter is finished with only one elucidated androktasia narrated in four verses (522-25). Concomitantly, Athene's interventions in the latter conflict amount to a brief exhortation of (and inspiration of menos in) Laertes to prayer (516-20) and an instruction to the Ithakans not to fight any longer (529-33); in the former she encourages Odysseus (who recognizes her) before being abused by the suitors and turning into a swallow (22.205-40), twice deflects the suitors' concerted casts $(256,273)$ and decisively employs the aigis to mark the end of the battle (297-309). The point of this element in the diminution is to focus on resolution as the result not merely of Athene's favor to Odysseus, but Zeus's guarantee that a settlement is necessary (cf. esp. 24.539-45).

\footnotetext{
${ }^{25}$ I suspect that it is the emotional impact of this second sequence which has caused scholars to treat this passage very much sui generis, obscuring its relationship with other closures in early hexameter texts. There is naturally much more to be said about the nature of these two sequences, but my primary purpose is to illuminate their obvious structural kinship.

${ }^{26} \mathrm{Cf}$. above, p. 372, for a summary reference to earlier discussions, among which Wender 1978 is essential (among the works in favor of authenticity); also S. West 1989; Seaford 1994: 38-42; Olson 1995: chs. 8-10; Foley 1999: ch. 5, esp. 157-67; Gainsford 2003.
} 
Furthermore, consider the flexible ways in which the final books of the Iliad and Odyssey reach back into their narratives. In both cases, motivating actions are required for the final episode, but these need not be mapped in too rigid a way onto the text's past in order to find a single predominant parallel. In the Iliad, after a largely "timeless" summary of Akhilleus's treatment of Hektor's corpse (24.1-22), the poet begins the narrative of the final book with a divine agore (23-76) which sets in train the process of drawing Thetis to heaven and then to Akhilleus (77-142), to form the ground for Priam's journey. Then another mission is sent to Priam himself (143-88), whose preparation and progress is described in full until his reception by Akhilleus and return to Troy with Hektor's corpse (189-718) before the closing lamentations. The first episode may reflect any of the divine agorai in the course of the poem, but its most obvious reminiscence is to the first assembly in A, where (in reverse order) Thetis approaches Zeus and then he must face the other gods in the light of his determination to grant her supplication. Though Iris's mission to Priam (24.159-88) reflects all the varied ways and several occasions on which the gods interact with humans (frequently without the latter's best interests in mind), Priam's following caution in seeking some assurance of the message's import compares most directly with Akhilleus's similarly sceptical reception of Iris's arrival to spur him to save Patroklos's corpse (18.166-202). This matching theme continues, because the ransom of Hektor is highly reminiscent of the battle over Patroklos's body, in the obvious sense that both are concerned with a dangerous mission to recover a corpse. The latter has been the aim of the poet and his audience since Zeus first mentioned it (8.475-76), but predicted more generally by the repetition of the Leichenkampf motif on several levels throughout the poem. ${ }^{27}$ Parallels could be multiplied, but the point remains that the preliminary actions of the final book reflect synecdochically the events and themes of much of the preceding poem.

This is even more true of the Odyssey. After a prudent recapitulation (esp. 23.333-37) of his adventures, Odysseus journeys to the fields to muster his forces for the inevitable counterattack (23.366-72). Then there occurs the so-called second Nekuia (24.1-204), in which the suitors' souls journey to Hades and engage (Akhilleus and) Agamemnon in conversation, and which patently recalls the first Nekuia, which Odysseus himself narrated in $\lambda$. These two scenes both dwell on the themes of Odysseus's marriage and return

${ }^{27}$ The first struggle over and claiming of a corpse occurs at 4.505-7; cf. generally Segal 1971. 
(though with a significant difference in the source of the information), ${ }^{28}$ the

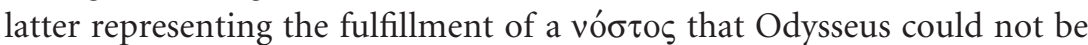
sure about when he spoke to the Phaiakians in the former. In addition, the parallelism expresses the extraordinary qualities of a hero who has managed to visit Hades and not only lived to tell the tale, but also to send his enemies there on their only trip. Further, while Odysseus's subsequent gathering of his allies (24.205-411) is a necessary precursor to the final battle (for he cannot fight alone), it reflects more generally the long drawn-out recruitment of the members of his family and household (Eumaios, Telemakhos, Eurykleia, Philoitios) on which the hero has been engaged since his arrival on Ithaka. As part of this process, the much-maligned recognition scene with Laertes (220-362) resumes and concludes the poem's constant exploration of the themes of disguise and testing (cf. Murnaghan 1986; Gainsford 2003), and picks up on the several earlier indications that the father is of some interest to the poet (cf. 1.188-93, 4.735-54, 11.187-96, 15.353-7, 16.137-53, 22.184-6; de Jong 2001 ad Od. 1.188-93: 27; contra S. West 1989). The final agore of the Odyssey (420-71) before the battle itself, in which Antinoos's father Eupeithes incites some portion of the community to revenge, reaches back to the gathering in the second book of the poem, where the same themes- the community's responsibility for the situation, the coming destruction of those who offend against Odysseus's household-are explored now from a more privileged perspective. Constant to all these reminiscences is a diminution in scale and intensity, as the lessons earlier learned by the audience and the characters are now applied and exercised for the final time in the poem.

There are, certainly, many ways to doubt and defend the authenticity of this portion of the poem, but the analysis above has suggested that, from a structural point of view, the ending of the Odyssey seems perfectly in accor-

${ }^{28}$ Such a comparison, i.e., between the sources of a tale or figure, is analogous to the poet's contrast between his own narrative of the quarrel in the agore during A and

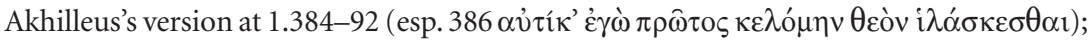
cf. de Jong 1985. One might therefore suggest that a more precise purpose to the reminiscence of the first Nekuia is to allow the audience to contrast Odysseus's depiction of Akhilleus with the poet's own account of the same character (compare esp. 11.488-91 and 24.30-3). This permits reflection on Odysseus's rhetorical purposes and abilities, based on an allusion to his traditional opposition to Akhilleus (evinced e.g. in their confrontation in the assembly in T, and Demodokos's first song in $\theta$; cf. Nagy 1979: 1-58; Garvie 1994: 248-50). It is typical of those abilities, as well as revealing of Odysseus's character, that he should describe his own choice-to survive and have a nostos by any means neces-

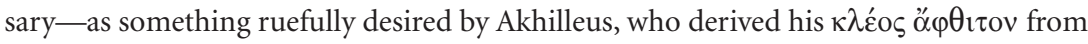
a short life, and death in Troy. 
dance with the Iliad's technique of closure. One could immediately object that this proves nothing more than the interpolator's familiarity with the Iliad, to which he has tried to create a resemblance in the Odyssey. This argument cannot be refuted, but it can be undermined by showing that this strategy of closing with a decreasing doublet is also to be found in the Hesiodic poems, to which I now turn.

\section{b. The Works and Days}

Lacking a narrative framework to carry its audience along, the structure of the Works and Days has posed serious problems for its critics. ${ }^{29}$ I suggested above that an $I D$ was employed to link the mythological section of the poem with the Works, and here I argue that its latter portion (276-825) is structured around a DDin which the Works are the first sequence and the Days the second. These two sections are separated by a passage of instruction (695-764), which is the second, smaller, sequence in the $D D$ to an earlier passage of instruction (274-382)_itself the last element of the increased sequence in the earlier ID - as the progressively more personalized and direct instructions come to dominate that final section before the Works (274-382 [IA below] = IIB in Fig. 2 [above, p. 381]). Where one fixes the beginning of that earlier, larger gnomic sequence is immaterial, for the audience will simply compare the scale of that prior sequence of instructions with the current one to deduce an intimation of closure (see Fig. 3).

Notice, first of all, the decrease in scale from I to II as a whole and in terms of the constituents: the second sequence is not only much shorter than the first, but its individual units are also strikingly attenuated. This is even more noticeable in IIB because the day is naturally a subdivision of the month, while the basic unit of IB is the season, a larger period than the month and more suitable in the Archaic period for the fixing of the farming calendar. ${ }^{30}$

${ }^{29}$ For treatments of its structure, cf. above, n18; I have for the moment postponed discussion of the Nautilia (618-94) and the authenticity of 826-28. For the former, cf. below, pp. 388-89 and Fig. 4; for the latter, p. 389.

${ }^{30}$ Cf. West 1978: 376-81. Stephanie West cautions me about assuming too much calendar consciousness or understanding in an archaic audience, pointing to the fact that "Herodotos 1.32 miscalculates the number of days in 70 years in a way that shows he doesn't understand the calendar." This is a salutary warning, but Hesiod's decision to structure his account of the farming year around seasons within it, and his constant definition of the days in relation to their position within the month (e.g.,

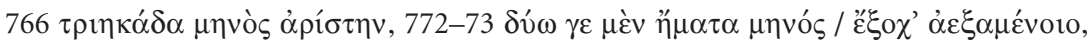

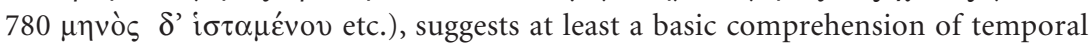
divisions within a larger whole. Unless we assume that Hesiod is the first poet to 


\begin{tabular}{|llll|}
\hline I & A & $274-382$ & (increasingly) direct advice \\
& B & $383-617$ & Works \\
\hline & & & \\
II & A & $695-764$ & direct advice \\
& B & $765-825$ & Days \\
\hline
\end{tabular}

Figure 3. Works and Days 276-825

What, aside from structural clarity, is gained by the poet's use of the $D D$ ? It was argued above that the elaboration of $\delta i \kappa \eta$ in all its forms is the focus of the narrative of the proem, the mythological section of the poem, and the transitional ID identified earlier (cf. above, pp. 380-81). Given that, in these earlier sections, Hesiod has set out in mythological terms the several reasons why Zeus has ordained work for mankind, now the $D D$ sets out how that ordination is to be played out in the yearly, monthly and daily routine of man. The narrowing of the focus, both temporally and spatially, reinforces the inexorable nature of the Dike of Zeus and his complete control over, and responsibility for, the rhythms of human life. In this case, and unlike the Iliad and Odyssey, the audience is not directly comparing the situations of the earlier and current sequences-except insofar as the Days is the more closely focused delineation of the themes informing and underpinning the Works. Thus the doublet serves several interpretative purposes, beyond simply letting the audience know that the poet is coming to an end (though this is important).

The Nautilia was omitted from the diagram above, but it should now be considered. This passage is itself a DD within the Works, as one can see from Figure 4.

Aside from the poet's obvious contrast between farming and sailing as the more and less preferred means for pursuing the necessities of life (as

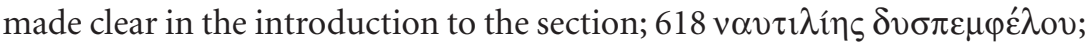
cf. Griffith 1983: 60-2; Rosen 1990; Nelson 1998: 165-69; Clay 2003: 45-46, 146), the parallel between the two is evident in that both farming (specifically plowing) and sailing have two seasons for the activity in question (485-92 I 678-85). The usual observations of scale apply here, not only in terms of verses

come up with these subdivisions, which seems extremely unlikely even without, e.g., $\mathrm{Od}$.

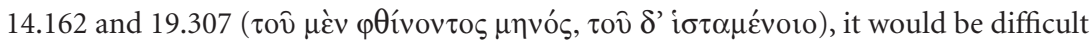
to deny some contemporary ability to recognize these types of divisions. 


\begin{tabular}{|c|c|c|}
\hline I & $383-617$ & Farming \\
\hline II & 618-94 & Sailing \\
\hline
\end{tabular}

Figure 4. Works and Days 383-694

but also the number of months over which the activities are detailed, with agricultural tasks extending over the whole year and nautical ones possible for only two seasons. This decrease in scale expresses the poet's preference for farming (even if sailing is viewed as a supplementary activity), but also helps to mark the end of the Works section.

The second postponed question concerns the authenticity of 826-28

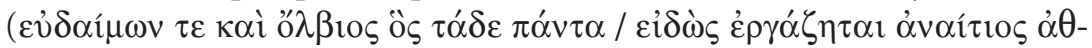

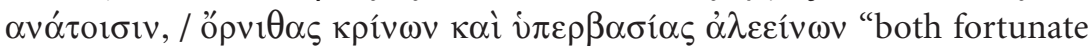
and blessed (is he) who, knowing all these things / works without blame from the immortals, / discerning the birds and avoiding transgressions"), ${ }^{31}$ which was known to-and athetised by-Apollonios of Rhodes (Cf. Schol. vet. ad loc.; also West 1978: 364-65). The criterion of the DD guarantees at least up to 825 , and perhaps also $826-27$, for it is only the predicative participles in 828 that actively militate against the closure of the poem. П5 (P. Vindob.

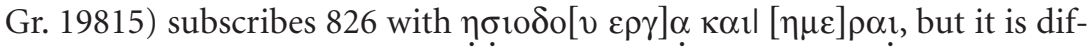
ficult to know whether this is an independent witness (from Apollonios) to a manuscript tradition lacking some or all of the final three verses. In fact, the $D D$ criterion can only suggest that the Days was the final section of the poem as originally intended, and that the Ornithomanteia (whether or not the work of Hesiod) was joined to it later. ${ }^{32}$

\section{c. The Theogony}

The Theogony contains more $D D s$, making the authenticity of its ending more difficult, and so more interesting. After the $I D$ traced above is concluded with the establishment of Zeus's reign, the poet immediately turns to a $D D$, generating the conflict between Zeus and Typhaon (820-85) as the second

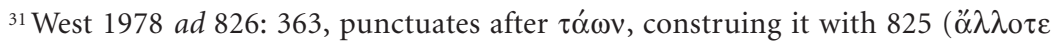

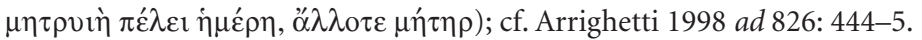

${ }^{32}$ For the arguments over the end of the Theogony, and the resemblances between the Works and Days and Theogony in these respects, cf. below, pp. 389-96, esp. 394-96. 
sequence to the Titanomachy. ${ }^{33}$ Note the process of that sequence: Earth's generation of Typhaon is followed by his description, then conflict with Zeus, and a summary of the settlement among the gods. This parallels the general process of each sequence in the ID (i.e., generation preparing for conflict), ${ }^{34}$ but the Typhaon passage is more closely modeled on the larger one (211-819) because they both close with a passage detailing the divine settlement after the fighting (see Fig. 5).

I pass over the usual diminution in scale with minimal comment, but the conflict with Typhaon indicates a coming end to the poem, or perhaps only to the stage of open conflict among the gods in the establishment of Zeus's reign. The thematic significance of this diminution comes from the fact that Zeus himself conquers Typhaon, who is a risk to his reign generated by the usual dangerous female (in this case, Gaia), and that he does so without aid from anyone else..$^{35}$ In short, the victory justifies his personal authority to rule over the gods for, although he was indeed very prominent in the Titanomachy, the Hundred-Handers played a key role reflected in the broader epic tradition. ${ }^{36}$ Moreover, Hesiod's decision to generate the Typhaonomachy as a $D D$ with the Titanomachy has removed this story from its usual place within the narrative of Zeus's reign, for Typhaon's birth is elsewhere the result of Here's angry reaction to Athene's birth (cf. Homeric Hymn to Apollo (3) 305-52; also West 1966 ad Theogony 820-80: 379-83). The poet's choice thus downplays the potential for stasis in the current generation of gods, and the power of Here within that generation, and so reinforces the security of Zeus. ${ }^{37}$

Nonetheless, this $D D$ raises the question of the authenticity of everything from 886 on, and the substance of the Theogony from this point has been

${ }^{33}$ Cf. above, pp. 377-80, and Fig. 1. This is paralleled by the case just examined from the Works and Days where the second sequence in the ID before the Works (IIB in Fig. 2) also serves as the first sequence in the concluding DD (IA in Fig. 3), which could be an argument for Hesiodic (or, at any rate, the same poet's) authorship of both poems.

${ }^{34}$ This was also the scheme used before the overthrow of Kronos and the defeat of Prometheus, the first preceded by the generation of the Kronidai and the second by that of the Iapetidai; cf. above, n16. Given the structural prominence afforded thereby to the Titanomachy, the diminution of the Typhaonomachy becomes even more apparent.

${ }^{35}$ Aside from the works cited on p. 380 above, cf. Blaise 1992.

${ }^{36}$ Cf. Il. 1.401-6. They are the first children of Gaia and Ouranos in the "cyclic" Theogony (arg. 1-4 Bernabé 1987), Aigaion / Briareos fights on the side of the Titans in the Titanomachy (F 3 Bernabé 1987), and in Kinaithon's Herakleia he is on the wrong end of a contest with Poseidon (F 7 Bernabé 1987); cf. also West 1966 ad Theogony 149: 210.

${ }^{37}$ For other ways in which Here's disruptive potential is overcome, cf. below, pp. 393-94. 


\begin{tabular}{|ccll|}
\hline I & A & $211-616$ & $\begin{array}{l}\text { Generation (children / grandchildren of } \\
\text { Nyx \& Pontos; grandchildren } \\
\text { of Gaia) }\end{array}$ \\
& B & $617-716$ & $\begin{array}{l}\text { Titanomachy } \\
\text { Settlement }\end{array}$ \\
C & $717-819$ & \\
\hline & & & Generation \\
II & A & $820-35$ & $\begin{array}{l}\text { Typhaonomachy } \\
\text { B }\end{array}$ \\
& $836-80$ & \\
C & $881-5$ & \\
\hline
\end{tabular}

Figure 5. Theogony 211-885

doubted or excluded by a number of editors (cf. West 1966: 397-99, 437; Hamilton 1989: 96-99; Dräger 1997: 1-26; Arrighetti 1998: 368-71). One might argue, on the basis of the $D D$ above, that the following catalogues (i.e., everything until 1022) are a later addition. However, the security of Zeus's regime depends in large part on his failure to resemble either his father or his grandfather-especially with respect to the goddesses. Where they go wrong is to have all their most powerful children by one female figure (Gaia or Rheia), who thus becomes an alternative source of loyalty within the supreme oikos. The comparison between Zeus and Kronos was earlier highlighted by the ID (cf. above, pp. 377-80), so on these grounds the generation of the Olympians' progeny could be defended as part of the poem's original conception. Furthermore, the MSS betray no trace of disruption, and some further genealogy beyond the usual scheme of children and grandchildren in the poem's three major lines (Gaia and Ouranos, Night, and Pontos) is

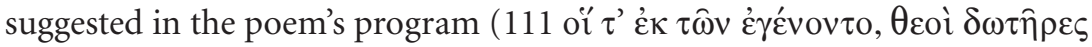
¿́ó $\omega \mathrm{v}$ "and those born from them, the gods, givers of good things") ${ }^{38}$ after the tripartite mission statement (106-7; cf. above, p. 377). Finally, note that the Nautilia in the Works and Days provides a parallel for a "preliminary" DD which signals only the end of a section, not the poem (cf. above, pp. 388-89 [and Fig. 4]), so the DD here (Titanomachy - Typhaonomachy) need not damn the following catalogues.

But the problem of authenticity is not hereby solved for, as Clay (2003: 162-64) notes, there are three broad segments to the rest of the poem

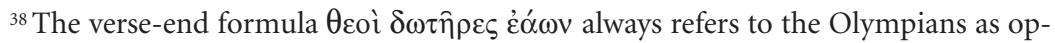
posed to the Titans $(46,111,633,664)$; cf. West 1966 ad 46: 172; also Od. 8.325, with Garvie 1994 ad loc.: 306. 
(886-1022): a catalogue of Zeus's wives and immediate progeny (886-929), a more heterogeneous catalogue of divine unions with (eventually) divine offspring (930-62), and then a catalogue of goddesses who were joined with mortals (963-1018) which is introduced by a transitional device (963 i $\mu \varepsilon \hat{\imath} \varsigma$

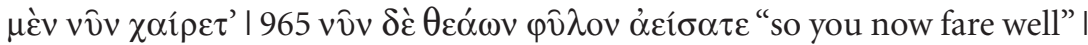
"but now sing the race of goddesses") found at the end of the Homeric Hymns (cf. above, n9). It seems that, if one grants the arguments of the last paragraph any weight, one has three main choices. ${ }^{39}$

The first is to excise the second and third of these catalogues (i.e., from 930 onwards), on the grounds that the first is clearly unified (starting and ending with the birth of Athene; cf. below, however) but the next two are more disparate. Though the genealogy of Zeus's children would thereby be worryingly incomplete (even missing out such central figures as Hermes and Herakles), the DD criterion could be invoked to support the excision; this smaller catalogue of Zeus's immediate children could be considered a more focused list of the important deities who buttress his rule, and so a natural $D D$ to the wider genealogies seen earlier in the poem. Certainly this catalogue expresses his generational superiority in the way that, say, the next segment (930-62) does not, introducing as it does other divine fathers. Nonetheless, 886-929 would be too sudden a conclusion; in the Iliad and Odyssey the poet goes to some lengths to prepare the audience for the concluding $D D$, and in the Works and Days the decreased Days section is not simply tacked onto the Works but separated from it, and so prepared for, by the second (smaller) sequence of direct advice (cf. above, pp. 382-87 [Iliad and Odyssey] and 387-89 [ Works and Days]).

The second choice is to excise only the third catalogue, on the grounds mainly of its opening transitional formula, and perhaps also because the poet now moves away from those (eventually) divine children who directly support Zeus's rule, and into the realm of mortals. The concluding DD would then comprise elements outlined in Figure 6a.

The structural parallels between the two center around their ring composition: I begins and ends (almost; cf. below) with Athene (888-900 | 924-26), II with children of sea deities (930-33 | 955-56). In each case, there is then a further act of generation (Hephaistos 927-28 I Medeia 958-62). The decrease in scale between the two catalogues is maintained (44 as opposed to 33 verses), and the picture is certainly more complete than it would be if the poem ended at 929.

\footnotetext{
${ }^{39}$ I postpone for the moment discussion of the Theogony's relationship with the Catalogue of Women, and the authenticity or otherwise of verses 1019-22.
} 


\begin{tabular}{|lll|}
\hline I & $886-929$ & catalogue of Zeus's immediate children \\
\hline II & $930-62$ & $\begin{array}{l}\text { catalogue of divine unions with (eventually) } \\
\text { divine children }\end{array}$ \\
\hline
\end{tabular}

Figure 6a. Theogony $886-962$

Nevertheless, this is not an obvious conclusion to the Theogony, since the diminution is nowhere near as clear as it is at the end of the Iliad, the Odyssey or the Works and Days (11 verses is not much of a difference), nor is thematic comparison between the two lists overwhelmingly apparent, as the poet moves from Zeus as sole father (I) to Zeus among the other gods as fathers (II). Furthermore, the last element outside the ring in each section is resumed in the middle of the next catalogue; Hephaistos (last item in I) marries Aglaia in the middle of II (945-46), whilst Medeia (last item in II) reappears with Jason and her son Medeios in the centre of the catalogue of goddesses and mortals (992-1002)..$^{40}$ This resumptive device suggests no small degree of care in joining this last list with the previous two. ${ }^{41}$ One could argue that this precisely the type of thing interpolators use to conceal their activities, but the $\mathrm{DD}$ argument here is not strong enough to exclude the last catalogue.

The third choice is to accept all three lists. This arrangement is powerfully supported by the $D D$ criterion (see Fig. 6b).

\begin{tabular}{|ccc|}
\hline I & $886-962$ & $\begin{array}{c}\text { catalogue of immortal fathers and } \\
\text { husbands } \\
\text { A }\end{array}$ \\
B & $\begin{array}{c}886-926^{42} \\
930-62\end{array}$ & $\begin{array}{c}\text { catalogue of Zeus's unions } \\
\text { catalogue of divine unions with divine } \\
\text { children }\end{array}$ \\
II & $963-1018$ & catalogue of immortal mothers and wives \\
\hline
\end{tabular}

Figure 6b. Theogony 886-1018

${ }^{40}$ One might also point to the fact that Harmonia and Kadmos's marriage in II (937) is then resumed in the catalogue of goddesses and mortals (975-78). Indeed, Herakles himself, who is granted apotheosis (954-45), is proleptic of the blurring between divine and mortal to come in the next catalogue.

${ }^{41}$ Cf. also below, pp. 394-96, for other patterning links between each of the three catalogues.

${ }^{42}$ On Here's intrusion into the sequence (927-29), cf. below. 
With a more pronounced diminution in both size (77 as opposed to 56 verses) and complexity, the $\mathrm{DD}$ is also made clear to the audience by the transitional formula at the start of II (963-68), for the consequent narrowing of focus proceeds simultaneously with the reduction in the power and freedom of the female deities. Indeed, one obvious advantage of this scheme is that it expresses structurally one of the most important lessons Zeus-and the audience-has learned about the nature of divine power: the subordination of the goddesses to the gods (with Zeus at their head), and specifically in their roles as figures of generation. Sequence I is constructed from the male perspective, in that every entry in the catalogue (but one; cf. below) has a divine father or husband, as well as divine issue, whilst II is structured around goddesses joined with mortals, with either divine or mortal issue (cf. Clay 2003: 162-64; West 1966: 16-18, 39). Between the two sequences, in other words, there is a progression from the primacy of the male deity over the female (I) to that of the female deity over the male mortal (II).43 This gendered hierarchy of power makes a particularly suitable ending to a poem in which the female has often proven to be the male's subversion and overthrow (cf. Clay 2003: 164-65).

That this is an issue at all in this section of the poem is made explicit, firstly, in the way that Here's parthenogenesis of Hephaistos is added to the end of IA in order to underline her anger with Zeus over the birth of Athene (927-29) (cf. Homeric Hymn (3) to Apollo 308-10; West 1966: 401-3). She is the only female figure in this section of the catalogue to give birth without Zeus - and

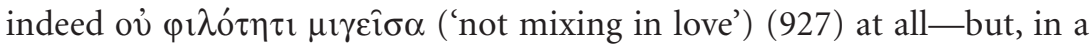
list of entries making the point of Zeus's dominance, Here's structural and generational anomaly are mutually emphatic. Clay has well shown how the poet in IB secures Zeus' reign by neutering through marriage the potential threat from Here's children (Ares, Hephaistos, Hebe), relegating Poseidon to his watery realm (esp. 931-33), and the birth of three more children to Zeus by a variety of wives (Hermes, Dionysos and Herakles) with, when required, appropriate acts of apotheosis (942, 954-55; cf. 949) (cf. Clay 2003: 162-65). Another advantage of the $D D$ above is that it places these two generational sequences together, where they belong theologically, and contrasts them much more strongly with the deflection of the goddesses' parturitive potential to the race of mortals, where they can be no threat to Zeus.

On this view, everything from 886 until 1018 must be authentic, but the problem of 1019-22 (postponed above) presents a problem of a different

${ }^{43}$ Compare the thematic progression from indirect to direct advice in Works and Days 202-382 (above, pp. 380-81 and Fig. 2). 
order. The similarity between the transitional formula at the start of II (963

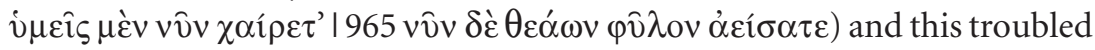

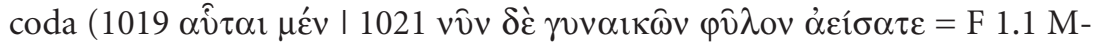

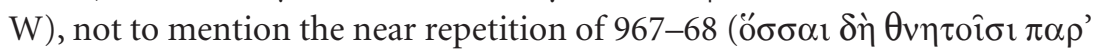

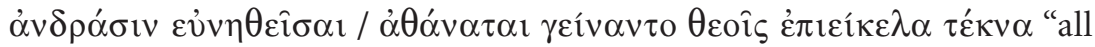
those who, bedded beside mortal men, / goddesses bore children alike to the

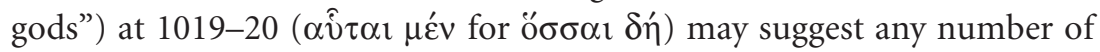
things, depending on one's critical preconceptions. ${ }^{44}$

As a starting point, the DD criterion suggests that the Catalogue of Women (whether or not by Hesiod) cannot have been part of the Theogony as originally intended. While 1021-22 are therefore definitely not original, 1019-20 are not decisively damned. Indeed, the parallel with the opening and closing of the Days sequence in the Works and Days (765-69 I 822-25 [and f.]) might argue that such a ring as in 1019-20 is at least Hesiodic. However, at Works and Days 823 the particle $\mu \varepsilon^{\prime} v$ is immediately answered by $\delta \varepsilon^{\prime}$ in order to differenti-

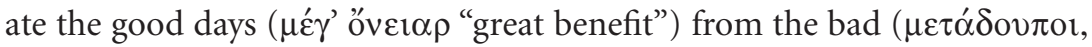

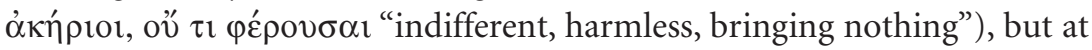
Theogony $1019 \mu \mu^{\prime} v$ is not answered or resumed at all except by reference to a new (and very large) list. Thus Works and Days 822-23 cannot be invoked as an argument in favor of the authenticity of Theogony 1019-20, which falls with 1021-22, but it was probably by reference to this parallel between the poems that the interpolation arose. ${ }^{45}$

There may be another reason to doubt the need for 1019-20 at all (i.e., as a summary of the information contained in the last catalogue) and that is that each of the three catalogues IA, IB and II end with a double entry: IA with Athene and Hephaistos's parthenogenesis (924-26 I 927-29), IB with the progeny of Perseis and Helios (956-57) followed by that of Aietes (their son) and Iduia (958-62), II with Odysseus's progeny first by Kirke (1011-16) and then by Kalypso (1017-18). Indeed, this last entry itself comprises a very small $D D$, both in terms of the number of verses but also in the fact that the first grouping has three children by Kirke, one of whom is amplified through

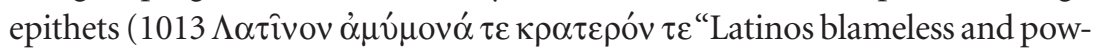

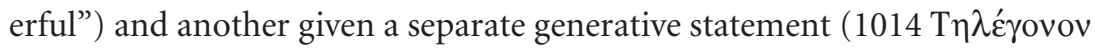

\footnotetext{
${ }^{44}$ For surveys of previous opinion, cf. West 1966: 397-9, 437; Arrighetti 1998: $368-71$.

${ }^{45}$ This may indicate that the joining of the Catalogue to the Theogony occurred later than the addition of the Ornithomanteia to the Works and Days, but even Works and Days 826-27 could be considered authentic (and so provide a sufficient parallel for an interpolator) without the explicit participle join in 828 .
} 


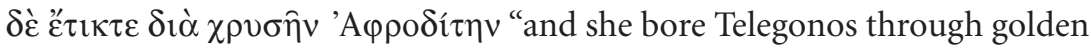
Aphrodite"), and the whole group described by a relative clause (1015-16 oi

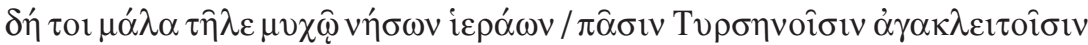
o'v $\alpha \sigma \sigma 0 v$ "who then very far away in a recess of holy islands / ruled over all the far famed Tyrsenians"); the second has only two children by Kalypso with no description at all. ${ }^{46}$ After the demonstration of the first section that IDs could be generated on small and (very) large scales, it should not be considered far fetched to see this last $D D$ as Hesiod's final codetta to his Theogony. In short, there is no need for a summary of any sort for the audience to intimate the poem's end.

To all this, one might object that there are too many DDs, and that the use of this device to end a section as well as a poem makes it very difficult to argue that the $D D$ could account for the increasingly delimited 'rings' of closure along the lines suggested above. But the process of ending the Iliad, Odyssey and Works and Days was complex, with each emphasized sequence in the $D D$ requiring substantial preparation and construction; in the same way, the repeated use of DDs at the end of the Theogony conveys to an audience a progressive sense of closure. As each sequence and catalogue gains its significance by its relationship and/or contrast with the preceding one(s), the genealogical lesson of Zeus's power is underlined and focused even as Zeus himself recedes from view.

\section{d. The Shield of Herakles}

The opening 56 verses of the Shield of Herakles are also found in the Catalogue of Women (F 195.8-64 M-W) and so, together with the difficulties surrounding the structure and origins of that entirely fragmentary poem, one might need to consider the skewing effects of "transitional" texts (i.e., those even more removed from an oral performance locus than the oral-derived epics considered hitherto). As the spread of literacy begins to influence the traditional style of composition, might not that process result in a modification — indeed abandonment_-of some of the older structural practices? Apparently not. Whatever the relationship between 1-56 and the rest of the poem, the encounter between the combatants is constructed around and closed by one large $D D$ (see Fig. 7).

${ }^{46}$ Furthermore, both Nausithoos and Nausinoos are obvious "redende Namen,"drawn with genealogical absurdity from the Phaiakians (West 1966 ad loc.: 436), whilst Agrios, Latinos and Telegonos all have separate existence (cf. West 1966 ad loc.: 433-34). I am unconcerned with the antiquity of the traditions underlying these figures, for it is enough for my purpose to note that Hesiod chose the more prominent names and figures for the first grouping. 


\begin{tabular}{|c|c|c|c|}
\hline I & $\begin{array}{l}\text { A } \\
\text { B } \\
\text { C }\end{array}$ & $\begin{array}{l}325-48 \\
349-66 \\
366-423\end{array}$ & $\begin{array}{l}\text { Preparations for combat and approach } \\
\text { Herakles to Kyknos (no reply) } \\
\text { Combat (corpse not stripped) }\end{array}$ \\
\hline II & $\begin{array}{l}\text { A } \\
\text { B } \\
\text { C }\end{array}$ & $\begin{array}{l}424-42 \\
443-50 \\
451-62\end{array}$ & $\begin{array}{l}\text { Preparation for combat and approach } \\
\text { Athene's challenge to Ares (no reply) } \\
\text { Combat (corpse stripped) }\end{array}$ \\
\hline
\end{tabular}

Figure 7. Shield of Herakles 325-462

The diminution of the second sequence is again clear, this time more from the totality of the sequence than the comparison of each of the individual elements (IA is only a few verses longer than IIA, though both IB and C are noticeably larger than their counterparts). After the second sequence, the poet then narrates the departures of the combatants in another $D D$, with the gathering of Ares and his flight to Olympos (463-66) being diminished in Herakles' and Iolaos's departure (467-70), before Athene herself departs (470-71). The problem raised by these departures - if one can call it a problem-is much the same as the Theogony's three diminishing catalogues, in which case the third departure is best considered the second sequence in a $D D$ to the two departures of the direct combatants (see Fig. 8).

The structure in that figure is supported by the consideration that each departure in I is preceded by an action concerning the victim of the combat, in the first case the gathering of Ares' prone figure by Phobos and Deimos, in the second the stripping of Kyknos's corpse by Herakles and Iolaos. Just as the first two catalogues at the end of the Theogony belong naturally together because of their subject matter and thematics, so here IA and IB are connected by an equation between their preceding actions, as well as the number of the agents. This makes a more noticeable contrast with the departure of Athene (seven and a half to one and a half verses), who plays in any case a less prominent role in the actual combat (only deflecting Ares' first spear thrust at 455-56), and whose presence is less the result of a concern with the relatively petty spoils of the fighting, or indeed Apollo's anger at Kyknos for despoiling pilgrims to his shrine, but a function of her support of Herakles as Zeus's son. ${ }^{47}$

\footnotetext{
${ }^{47}$ This aspect of her relationship with Herakles, emphasized in the Iliad (8.362-69), is expressed in this poem by the gift of a breastplate before he began his labors (124-27), her assurance to him of Zeus's favor before the combat (325-29), and her possession of the aigis (343-44); cf. Russo 1965 ad Shield 126: 103; also ad 325ff.: 158-59.
} 


\begin{tabular}{|c|c|c|c|}
\hline I & $\begin{array}{l}\text { A } \\
B\end{array}$ & $\begin{array}{l}463-70 \\
463-66 \\
467-70\end{array}$ & $\begin{array}{l}\text { Concern with victim and departures } \\
\text { Departure of Ares } \\
\text { Departure of Herakles }\end{array}$ \\
\hline II & & $470-71$ & Departure of Athene \\
\hline
\end{tabular}

Figure 8. Shield of Herakles 463-71

In this case, aside from closing the narrative, the $D D$ directs the audience to the hero's cosmological importance beyond this particular story.

The poem's final ten verses concern Kyknos's burial by Keyx and the destruction of his tomb by Apollo and the Anauros, an epilogue reminiscent of the Odyssey's closure with Athene's settling of ópкı (24.546-58) after the final battle, as well as the Works and Days' assertion of the value of its knowledge (822ff.), and it cannot obscure the careful structural decrease identified here (cf. van Groningen 1958: 70-77; also Janko 1986: 44-47). The date of the Shield is disputed, but the DDs above would indicate that traditional structural methods were still being used at the time of its composition. One cannot draw too many conclusions from this about the structure of the Catalogue of Women, because the evidence does not make it clear whether the Shield is to be considered an original part of the Catalogue, an addition to it by a later poet, or perhaps a pre-existing poem drawn from the many tales of Herakles which was later attached to the Catalogue at the end of the Alkmene entry (cf. West 1985: 136; Janko 1986: 38-39; Martin 2005: 171-75). One can say, however, that its poet was composing in a manner at least partially derived from that of his elders. ${ }^{48}$

\section{CONCLUSION}

This article has aimed to demonstrate that the extant examples of early Greek hexameter poetry reveal a consistent strategy of closure. Whilst the greater scale of the Iliad and Odyssey enormously increases the complexity of the decreasing doublet when compared to the Hesiodic examples, one can still observe a basic commonality between the surviving texts of the genre. Given that the practice is drawn directly from repetition, the genre's most basic structural imperative, and more specifically represents a form of doublet structure,

${ }^{48}$ For discussion of date and technique, cf. van Groningen 1958: 109-23; Russo 1965: 7-35; van der Valk 1961; Janko 1982: 78-79, 86, 127-28, 278n17 (and index, s.v.); Janko 1986: 38-40; Toohey 1988; Martin 2005. 
one of the poems' most studied and thoroughly understood compositional techniques, the pervasiveness of this strategy is readily and economically explained by an origin in the context of oral recomposition in performance; however distant from this context are the texts examined here, one can see that the interplay between orality and literacy in Archaic Greek culture was a continuative dynamic, and not a moment of irrevocable disjunction. ${ }^{49}$

Using the decreasing doublet as an analytical criterion permits a series of structurally driven judgments about the integrity of the endings to these poems. They are, in short, as follows: the Iliad ends where it should with the funeral of Hektor, the final book of the Odyssey is authentic, the Theogony did not originally contain the Catalogue of Women, and the Works and Days did not continue into the Ornithomanteia. When, where and how these continuations arose is beyond the scope of this article, but they are not without value, for they indicate the direction in which the solution to the problem may be located. By considering some of the most basic oral compositional techniques, one can see a way through the confusion heralded in the introduction to this article, a confusion which was not the work of the original poets. They, and I dare say their audiences, knew exactly what they were doing.

\section{WORKS CITED}

Allen, T. W. 1912. Homeri Opera Tomus V Hymni; Cyclus; Fragmenta; Margites, Batrachomyomachia; Vitae. Oxford: Clarendon Press.

Arrighetti, G. 1998. Esiodo. Opere. Turin: Einaudi-Gallimard.

Austin, N. 1966. “The Function of Digressions in the Iliad.” GRBS 7: 295-312.

Becker, O. 1937. Das Bild des Weges und verwandte Verstellungen im frühgriechischen Denken. Berlin: Weidmann.

Bernabé, A. 1987. Poetarum Epicorum Graecorum Testimonia et Fragmenta: Pars I. Leipzig: Teubner.

Blaise, F. 1992. "L'Épisode de Typhée dans la Théogonie d’Hésiode (v. 820-885): la stabilisation du monde." REG 105: 349-70.

Blusch, J. 1970. Formen und Inhalt von Hesiods individuellem Denken. Bonn: H. Bouvier.

Bonnafé, A. 1985. Eros et Eris: Mariages divins et mythe de succession chez Hesiode. Lyon: Presses Universitaires de Lyon.

Burgess, J. 2001. The Tradition of the Trojan War in Homer and the Epic Cycle. Baltimore: Johns Hopkins University Press.

${ }^{49} \mathrm{Cf}$., in general, Robb 1994. Of course, nothing in the preceding discussion should be held to preclude the existence of other closural strategies. All I have tried to do here is show that the $D D$ provides an audience with a closural framework, as it were, a general intimation of ending which the poet is then free to configure according to the aims, themes and actions of his composition. 
Clay, J. 2003. Hesiod's Cosmos. Cambridge: Cambridge University Press.

Diller, H. 1962. Die dichterische Form von Hesiods Erga. Wiesbaden: Verlag der Akademie der Wissenschaft und der Literatur.

Dräger, P. 1997. Untersuchungen zu den Frauenkatalogen Hesiods. Stuttgart: Steiner.

Edwards, M. W. 1986. “The Conventions of an Homeric Funeral.” In J. Betts, J. Hooker, and T. Green, eds. Studies in Honour of T. B. L. Webster Volume I. Bristol: Bristol Classical Press. 84-92.

Erbse, H. 1977. Scholia Vetera ad Homeri Iliadem V: $\Upsilon$ - $\Omega$. Berlin: de Gruyter.

Fenik, B. 1974. Studies in the Odyssey. Wiesbaden: Steiner.

Finnegan, R. 1977. Oral Poetry: Its Nature, Significance and Social Context. Cambridge: Cambridge University Press.

Foley, J. M. 1999. Homer's Traditional Art. Philadelphia: Pennsylvania University Press.

- 2002. How to Read an Oral Poem. Urbana: University of Illinois Press.

Ford, A. 1992. Homer: The Poetry of the Past. Ithaca: Cornell University Press.

Fröhder, D. 1994. Die dichterische Form der Homerischen Hymnen. Zürich: Olms.

Furley, W. D., Bremmer, J. M. 2001. Greek Hymns; Selected Cult Songs from the Archaic to the Hellenistic Period Volume I: The Texts in Translation. Tübingen: Mohr Siebeck.

Gainsford, P. 2003. "Formal Analysis of Recognition Scenes in the Odyssey." JHS 123: $41-59$.

Garvie, A. 1994. Homer: Odyssey Books VI-VIII. Cambridge: Cambridge University Press.

Graziosi, B. 2002. Inventing Homer: The Early Reception of Epic. Cambridge: Cambridge University Press.

di Gregorio, L. 1975. Scholia vetera in Hesiodi Theogoniam. Milan: Vita e pensiero.

Griffith, M. 1983. "Personality in Hesiod." ClAnt 2: 37-65.

van Groningen, B. A. 1958. La composition littéraire archaïque grecque: Procédes et realisations. Amsterdam: Noord-Hollandsche Uitg. Mij.

Hamilton, R. 1989. The Architecture of Hesiodic Poetry. Baltimore: Johns Hopkins University Press.

Heath, M. 1985. “Hesiod's Didactic Poetry.” CQ n.s. 35: 245-63.

Heiden, B. 1996. "The Three Movements of the Iliad." GRBS 37: 5-22.

_ 1998. "The Placement of the Book-Divisions in the Iliad." JHS 118: 68-81.

2000. "Narrative Discontinuity and Segment Marking at Iliad 3 / 4, 7 / 8, and 10

/ 11, and Odyssey 4 / 5, 17 / 18, and 23 / 24." C\& M 51: 5-16.

Heubeck, A. 1992. “Books XXIII-XXIV.” In J. A. Russo, M. Fernández-Galiano, and A. Heubeck, eds. A Commentary on Homer's Odyssey Volume III: Books XVII-XXIV. Oxford: Clarendon Press.

Hubbard, T. 1995. "Hesiod's Fable of the Hawk and the Nightingale Reconsidered." GRBS 36: $161-71$.

Hunter, R., ed. 2005. The Hesiodic Catalogue of Women: Constructions and Reconstructions. Cambridge: Cambridge University Press.

Janko, R. 1981. “The Structure of the Homeric Hymns: A Study in Genre." Hermes 109: 9-24.

-1982. Homer, Hesiod and the Homeric Hymns. Cambridge: Cambridge University Press.

1986. "The Shield of Heracles and the Legend of Cycnus." CQ n.s. 36: 38-59. 
_. 1998. “The Homeric Poems as Oral Dictated Texts." CQ n.s. 48: 1-13.

- 1999. Review of Nagy 1996. JHS 118: 206-7.

de Jong, I. 1985. "Iliad 1. 366-92: A Mirror Story." Arethusa 18: 1-22. Reprinted with minor revisions in D. L. Cairns, ed. Oxford Readings in Homer's Iliad. Oxford: Oxford University Press. 478-95.

- 2001. A Narratological Commentary on the Odyssey. Cambridge: Cambridge University Press.

Kerschensteiner, J. 1944. “Zu Aufbau und Gedankenführung von Hesiods Erga.” Hermes 79: 149-91.

Kirk, G. S. 1962. "The Structure and Aim of the Theogony.” In Hésiode et son influence (Fondation Hardt VII): Six exposés et discussions. Geneva: Fondation Hardt. 63-95.

Kumaniecki, K. 1963. “The Structure of Hesiod's Works and Days.” BICS 10: 79-96.

Lardinois, A. 1999. "How the Days Fit the Works in Hesiod's Works and Days." AJP 119: 319-36.

Latacz, J. 2000. Homers Ilias Gesamtkommentar: Prolegomena. Munich: K. G. Saur.

Lonsdale, S. 1989. "Hesiod's Hawk and Nightingale (Op. 202-12): Fable or Omen?" Hermes 117: 403-12.

Lord, A. 1953. “Homer’s Originality: Oral Dictated Texts.” TAPA 84: 124-34. . 1960. The Singer of Tales. Cambridge MA: Harvard University Press.

Martin, R. 2005. "Pulp Epic: the Catalogue and the Shield." In Hunter, 2005. 153-75.

Merkelbach, R., M. L. West, eds. 1967. Fragmenta Hesiodea. Oxford: Clarendon.

Minton, W. 1970. “The Proem-Hymn of Hesiod's Theogony.” TAPA 101: 357-77.

Murnaghan, S. 1986. Disguise and Recognition in the Odyssey. Princeton: Princeton University Press.

Myres, J. 1932. “The Last Book of the Iliad: Its Place in the Structure of the Poem." JHS 52: 264-96.

Nagy, G. 1979. The Best of the Achaeans: Concepts of the Hero in Archaic Greek Poetry. Baltimore: Johns Hopkins University Press.

- 1996. Poetry as Performance: Homer and Beyond. Cambridge: Cambridge University Press.

Nelson, S. 1998. The God and the Land: The Metaphysics of Farming in Hesiod and Vergil. New York: Oxford University Press.

Nicolai, W. 1964. Hesiods Erga: Beobachtungen zum Aufbau. Heidelberg: C. Winter.

Nünlist, R. 1998. Poetologische Bildersprache in der frühgriechischen Dichtung. Leipzig: Teubner.

Olson, S. D. 1995. Blood and Iron: Stories and Storytelling in the Odyssey. Leiden: Brill. van Otterlo, W. A. A. 1944. Untersuchungen über Begriff, Anwendung und Entstehung der griechischen Ringkomposition. Amsterdam: Noord-Hollandsche Uitg. Mij.

Peabody, B. 1975. The Winged Word: A Study in the Techniques of Ancient Greek Oral Composition as Seen Principally through Hesiod's Works and Days. Albany: State University of New York Press.

Pertusi, A. 1955. Scholia vetera in Hesiodi Opera et Dies. Milan: Vita e pensiero.

Postlethwaite, N. 1995. “Agamemnon Best of Spearmen." Phoenix 49: 95-103.

Powell, B. 1970. "Narrative Patterns in the Homeric Tale of Menelaus." TAPA 101: 419-31. 
Reece, S. 1993. The Stranger's Welcome: Oral Theory and the Aesthetics of the Homeric Hospitality Scene. Ann Arbor: University of Michigan Press.

Reinhardt, K. 1961. Die Ilias und ihr Dichter. Göttingen: Vandenhoeck und Ruprecht.

Riedinger, J-C. 1992. “Structure et signification du 'Calendrier du paysan' d'Hesiode (Travaux vv. 383-617).” RPh 66: 121-41.

Robb, K. 1994. Literacy and Paideia in Ancient Greece. New York: Oxford University Press.

Roberts, D. H., Dunn, F. \& Fowler, D. P. eds. 1997. Classical Closure: Reading the end in Greek and Latin Literature. Princeton: Princeton University Press.

Rosen, R. 1990. "Poetry and Sailing in Hesiod's Works and Days." ClAnt 9: 99-113.

Russo, C. F. 1965. Hesiodi Scutum. Florence: La nuova Italia.

Schadewaldt, W. 1966. Iliasstudien. 3rd ed. Berlin: Wissenschaftliche Buchgesellschaft.

Schein, S. 1997. “The Iliad: Structure and Interpretation.” In I. Morris and B. Powell, eds. A New Companion to Homer. Leiden: Brill. 345-59.

Schmidt, J-U. 1986. Addressat und Paraineseform: zur Intention von Hesiods Werken und Tagen. Göttingen: Vandenhoeck und Ruprecht.

Schwabl, H. 1966. Hesiods Theogonie. Eine unitarische Analyse. Vienna: Böhlau.

Seaford, R. 1994. Reciprocity and Ritual: Homer and Tragedy in the Developing City-State. Oxford: Clarendon Press.

Segal, C. 1971. The Theme of the Mutilation of the Corpse in the Iliad. Leiden: Brill.

Solmsen, F., R. Merkelbach, M. L. West, eds. 1983. Hesiodi Theogonia; Opera et Dies; Scutum; Fragmenta selecta. Oxford: Clarendon Press.

Stoddard, K. 2004. The Narrative Voice in the Theogony of Hesiod. Leiden: Brill.

Taplin, O. 1992. Homeric Soundings: The Shaping of the Iliad. Oxford: Clarendon Press.

Thalmann, W. 1984. Conventions of Form and Thought in Early Greek Poetry. Baltimore: Johns Hopkins University Press.

Thornton, A. 1984. Homer's Iliad: Its Composition and the Motif of Supplication. Göttingen: Vandenhoeck und Ruprecht.

Toohey, P. 1988. "An [Hesiodic] danse macabre: The Shield of Heracles." ICS 13: 19-35.

van der Valk, M. 1966. "Le Bouclier du Pseudo-Hésiode." REG 79: 450-81.

Verdenius, W. 1962. “Aufbau und Absicht der Erga.” In Hésiode et son influence (Entretiens Fondation Hardt VII). Geneva. 111-59.

Walcot, P. 1961. “The Composition of the Works and Days." REG 74: 1-19.

Wender, D. 1978. The Last Scenes of the Odyssey. Leiden: Brill.

West, M. L. 1966. Hesiod: Theogony. Oxford: Clarendon Press.

- 1978. Hesiod: Works and Days. Oxford: Clarendon Press.

- 1985. The Hesiodic Catalogue of Women. Oxford: Clarendon Press.

1999. “The Invention of Homer." CQ n.s. 49: 364-82.

West, S. 1989. "Laertes Revisited." PCPS 35: 113-43.

Whitman, C. 1958. Homer and the Heroic Tradition. Cambridge MA: Havard University Press.

Willcock, M. M. 1995. “The Importance of Iliad 8.” In Ø. Anderson and M. Dickie, eds. Homer's World: Fiction, Tradition, Reality. Bergen: Ström. 113-21. 